\title{
Fluoride Modulates Parathyroid Hormone Secretion in vivo and in vitro
}

\author{
Chaitanya P. Puranik ${ }^{a}$ Kathleen A. Ryan ${ }^{\text {b }}$ Zhaoyu Yin $^{c}$ \\ E. Angeles Martinez-Mier ${ }^{\mathrm{e}}$ John S. Preisser ${ }^{\mathrm{c}}$ Eric T. Everett ${ }^{\mathrm{d}}$ \\ ${ }^{a}$ Oral Biology PhD Curriculum, ${ }^{b}$ Oral and Craniofacial Health Sciences, and ${ }^{c}$ Department of Biostatistics, Gillings \\ School of Global Public Health, and d Department of Pediatric Dentistry, Carolina Center for Genome Sciences, \\ University of North Carolina at Chapel Hill, Chapel Hill, N.C., and e Department of Preventive and Community \\ Dentistry, Indiana University School of Dentistry, Indianapolis, Ind., USA
}

\section{Key Words}

Fluoride · Skeletal fluorosis · Parathyroid hormone · Bone . Inbred mouse strains

\begin{abstract}
The study objective was to investigate the effects of fluoride on intact parathyroid hormone (iPTH) secretion. Thyroparathyroid complexes (TPC) from C3H $(n=18)$ and $B 6(n=$ 18) mice were cultured in $\mathrm{Ca}^{2+}$-optimized medium. TPC were treated with 0,250 , or $500 \mu \mathrm{M} \mathrm{NaF}$ for $24 \mathrm{~h}$ and secreted iPTH assayed by ELISA. C3H $(n=78)$ and B6 $(n=78)$ mice were gavaged once with distilled or fluoride $(0.001 \mathrm{mg}$ $\left[\mathrm{F}^{-}\right] / \mathrm{g}$ of body weight) water. At serial time points (0.5-96 h) serum iPTH, fluoride, total calcium, phosphorus, and magnesium levels were determined. Expression of genes involved in mineral regulation via the bone-parathyroid-kidney (BPK) axis, such as parathyroid hormone (Pth), calciumsensing receptor (Casr), vitamin D receptor (Vdr), parathyroid hormone-like hormone (Pth/h), fibroblast growth factor 23 (Fgf23), a-Klotho (aKlotho), fibroblast growth factor receptor 1c (Fgf1rc), tumor necrosis factor 11 (Tnfs11), parathyroid hormone receptor 1 (Pth1r), solute carrier family 34 member 1 (S/c34a1), solute carrier 9 member 3 regulator 1 (S/c9a3r1), chloride channel 5 (Clcn5), and PDZ domain-containing 1
\end{abstract}

(Pdzk1), was determined in TPC, humeri, and kidneys at 24 h. An in vitro decrease in PTH was seen in $\mathrm{C} 3 \mathrm{H}$ and B6 TPC at $500 \mu \mathrm{M}(\mathrm{p}<0.001)$. In vivo levels of serum fluoride peaked at $0.5 \mathrm{~h}$ in both $\mathrm{C} 3 \mathrm{H}(\mathrm{p}=0.002)$ and $\mathrm{B} 6(\mathrm{p}=0.01)$. In $\mathrm{C} 3 \mathrm{H}$, iPTH decreased at $24 \mathrm{~h}(\mathrm{p}<0.0001)$, returning to baseline at $48 \mathrm{~h}$. In B6, iPTH increased at $12 \mathrm{~h}(\mathrm{p}<0.001)$, returning to baseline at $24 \mathrm{~h}$. Serum total calcium, phosphorus, and magnesium levels did not change significantly. Pth, Casr, aKlotho, Fgfirc, Vdr, and Pthlh were significantly upregulated in $\mathrm{C} 3 \mathrm{H}$ TPC compared to B6. In conclusion, the effects of fluoride on TPC in vitro were equivalent between the 2 mouse strains. However, fluoride demonstrated an early strain-dependent effect on iPTH secretion in vivo. Both strains demonstrated differences in the expression of genes involved in the BPK axis, suggesting a possible role in the physiologic handling of fluoride.

C 2015 S. Karger AG, Basel

\section{Introduction}

Fluoride has recognized actions on bone homeostasis [Everett, 2011]. Yan et al. [2007] investigated in 2 inbred strains of mice, $\mathrm{C} 3 \mathrm{H} / \mathrm{HeJ}(\mathrm{C} 3 \mathrm{H})$ and $\mathrm{C} 57 \mathrm{BL} / 6 \mathrm{~J}(\mathrm{~B} 6)$, fluoride actions on bone homeostasis. In $\mathrm{C} 3 \mathrm{H}$ mice, short-

\section{KARGER}

E-Mail karger@karger.com www.karger.com/cto
(C) 2015 S. Karger AG, Basel

$1422-6405 / 15 / 2006-0413 \$ 39.50 / 0$
Eric T. Everett, $\mathrm{PhD}$

School of Dentistry, University of North Carolina at Chapel Hill

Koury Oral Health Sciences Building, Room 4417 CB\# 7455, 385 South Columbia Street Chapel Hill, NC 27599-7455 (USA)

E-Mail eric_everett@unc.edu 


\begin{tabular}{ll}
\hline Abbreviations used in this paper \\
\hline Actb & B-actin \\
B6 & C57BL/6J strain \\
BPK & bone-parathyroid-kidney \\
C3H & C3H/HeJ strain \\
Casr & calcium-sensing receptor \\
Clcn5 & chloride channel 5 \\
Fgf1rc & fibroblast growth factor receptor 1c \\
Fgf23 & fibroblast growth factor 23 \\
Gapdh & glyceraldehyde 3-phosphate dehydrogenase \\
iPTH & intact parathyroid hormone \\
Pdzk1 & PDZ domain-containing 1 \\
Pth & parathyroid hormone \\
Pth1r & parathyroid hormone receptor 1 \\
Pthlh & parathyroid hormone-like hormone \\
Slc34a1 & solute carrier family 34 member 1 \\
Slc9a3r1 & solute carrier 9 member 3 regulator 1 \\
sRANKL & soluble receptor activator of nuclear factor- $\kappa \mathrm{B}$ ligand \\
Tnfs11 & tumor necrosis factor 11 \\
TPC & thyro-parathyroid complex \\
Tpo & thyroperoxidase \\
TRAP5b & tartrate-resistant acid phosphatase 5b \\
Vdr & vitamin D receptor \\
$\alpha$ Klotho & a-Klotho \\
\hline &
\end{tabular}

term systemic exposure to fluoride resulted in increased osteoclastogenesis as evidenced by increases in the following serum osteoclast biomarkers: intact parathyroid hormone (iPTH), soluble receptor activator of nuclear factor- $\kappa \mathrm{B}$ ligand (sRANKL), and tartrate-resistant acid phosphatase 5b (TRAP5b), along with a decrease in serum osteoprotegerin levels [Yan et al., 2007]. Osteoclast numbers along bone surfaces and the osteoclast potential of bone marrow cells were increased in $\mathrm{C} 3 \mathrm{H}$ mice as well. However, similar fluoride exposure in B6 mice favored anabolic responses, with increases in serum alkaline phosphatase activity and proximal tibia trabecular and vertebral bone mineral density.

PTH is responsible for calcium homeostasis and is released in response to hypocalcemia to normalize serum calcium levels [Potts, 2005]. PTH is an important component of the bone-parathyroid-kidney (BPK) feedback loop responsible for mineral homeostasis [Bergwitz and Juppner, 2010; Torres and De Brauwere, 2011]. Skeletal fluorosis results from systemic exposure to fluoride leading to calcification of ligaments, bone deformities, fractures, functional limitations, a disturbed mineral balance, and occasional pseudo-hyperparathyroidism [Teotia and Teotia, 1973; Teotia et al., 1998]. The mechanisms underlying altered PTH levels due to fluoride exposure are not understood. We hypothesized that PTH secretion is in- fluenced by direct effects of fluoride on the parathyroid gland. Our in vitro and in vivo experiments were directed to investigating early events following fluoride exposure on PTH secretion.

\section{Materials and Methods}

Animals

Ninety-six 5- to 6-week-old male mice, $\mathrm{C} 3 \mathrm{H} / \mathrm{HeJ}(\mathrm{C} 3 \mathrm{H})$ and C57BL/6J (B6) (The Jackson Laboratory, Bar Harbor, Maine, USA), were placed on a constant-nutrition no-fluoride diet [No. 5861; Test Diet ${ }^{\circledR}$, Richmond, Ind., USA; fluoride: 0 ppm, calcium: $0.60 \%$, phosphorus: $0.57 \%$, vitamin $\mathrm{D}_{3}: 2.2 \mathrm{IU} / \mathrm{g}$, and energy: 4.09 $\left.(\mathrm{kcal} / \mathrm{g})^{2}\right]$ and were provided with distilled drinking water ad libitum for 1 week for acclimatization. The mice were housed in the Division of Lab Animal Medicine facility at The University of North Carolina at Chapel Hill, an AAALAC (Association for Assessment and Accreditation of Laboratory Animal Care International)-accredited unit. Mice were placed in 12:12-hour lightdark cycles at a $21^{\circ} \mathrm{C}$ ambient temperature. All procedures involving vertebrate animals were approved by the Institutional Animal Care and Use Committee of The University of North Carolina at Chapel Hill.

\section{Parathyroid Gland Dispersed Cell Culture}

Mice were euthanized using $\mathrm{CO}_{2}$, and ventral neck dissections were performed to isolate and harvest thyro-parathyroid complexes (TPC) after microdissections. TPC were finely minced and transferred to 2 -ml centrifuge tubes with digestion buffer containing $1 \mathrm{mg} / \mathrm{ml}$ collagenase (Stem Cell Technologies, Vancouver, B.C., Canada) in dispase solution (Stem Cell Technologies). TPC were incubated at $37^{\circ} \mathrm{C}$ for $3 \mathrm{~h}$ with intermittent pipetting for homogeneous dispersion of cells. Dispersed cells were plated onto 6-well plates and incubated at $37^{\circ} \mathrm{C}$ at $5 \% \mathrm{CO}_{2}$ in $2 \mathrm{ml}$ prewarmed a-MEM (Sigma-Aldrich, St. Louis, Mo., USA) media with 10\% FBS (Clontech Laboratories, Mountain View, Calif., USA) and 1\% antibiotic-antimycotic (Sigma-Aldrich). Total calcium, magnesium, and phosphorus levels in media were adjusted to that of the serum in each strain of mice as follows: $\mathrm{C} 3 \mathrm{H}$ (calcium: $10.6 \mathrm{mg} / \mathrm{dl}$, phosphorus: $8.7 \mathrm{mg} / \mathrm{dl}$, and magnesium: $2.1 \mathrm{mg} / \mathrm{dl}$ ) and $\mathrm{B} 6$ (calcium: $10.4 \mathrm{mg} / \mathrm{dl}$, phosphorus: $10.3 \mathrm{mg} / \mathrm{dl}$, and magnesium: $2.9 \mathrm{mg} / \mathrm{dl}$ ). TPC from $\mathrm{C} 3 \mathrm{H}$ and $\mathrm{B} 6$ mice were prepared on 2 separate occasions using a total of 12 mice per strain. An initial study used $2 \mathrm{~F}$ concentrations $(0$ and $500 \mu \mathrm{M})$. This was repeated using additional mice, and $3 \mathrm{~F}$ concentrations were examined $(0,250$, and $500 \mu \mathrm{M})$. Media supernatants were collected at $24 \mathrm{~h}$, centrifuged, and stored at $-80^{\circ} \mathrm{C}$ until analysis.

\section{Gavage and Sample Collections}

Following acclimatization, 72 mice from both strains were randomly divided in 12 groups of 6 mice $(0.5,1,3,6,12$, or $24 \mathrm{~h})$ based on the time of sacrifice after the gavage dose, with control and test groups based on fluoride levels ( 0 or $100 \mathrm{ppm}$ ) in gavage. Additionally, 6 mice from both strains were assigned to the no-gavageat-baseline group. At the time of gavage, the mice were weighed and the gavage dose was calculated for each mouse $(0.001 \mathrm{mg}$ $\left[\mathrm{F}^{-}\right] / \mathrm{g}$ of body weight). Mice were anesthetized with ketamine- $\mathrm{HCl}$ $(90 \mathrm{mg} / \mathrm{kg})$ and xylazine $(14 \mathrm{mg} / \mathrm{kg})$ intraperitoneally. Sera were 
collected from anesthetized mice and stored at $-80^{\circ} \mathrm{C}$ until use. TPC, kidneys, and humeri were harvested, snap-frozen in liquid nitrogen, and stored at $-80^{\circ} \mathrm{C}$.

\section{ELISA and Biochemistry Assays}

Media supernatants and sera were analyzed for iPTH using 1-84 PTH ELISA Kits (Immutopics, San Clemente, Calif., USA). The intra- and interassay precision (coefficient of variation) for the iPTH ELISA was 3.2 and 8.4, respectively. Each ELISA plate had 6 standard and 2 control solutions for the determination of $\mathrm{R}^{2}$ values. The threshold $\mathrm{R}^{2}$ value was set at 0.95 . All ELISA plates demonstrated $R^{2}$ values $>0.98$. Each ELISA plate was read with 6 samples each from the control and test group in triplicates.

Serum levels of fluoride were determined using the direct fluoride microanalysis method [Vogel et al., 1990]. In this method, micropipettes pulled from glass capillary tubes are combined with a custom-made micropipette holder and used to dispense nanoliter-sized standards and serum samples (diluted 9:1 with TISAB III). Serum samples are extracted over a light table using the micropipette/micropipette holder and dispensed onto the surface of an inverted fluoride electrode (F-ISE) under a layer of mineral oil to prevent loss of fluoride. Using a micromanipulator and a microscope for viewing, the reference electrode is touched to the standard or sample drop, resulting in an electrometer millivolt reading. Both the F-ISE and the hand-pulled reference electrode are connected to an electrometer and a computer with plot program monitoring/recording software. Samples are run in triplicate, with periodic electrode conditioning and standard checks.

Calcium, phosphorus, and magnesium levels were determined by the Animal Clinical Laboratory, University of North Carolina at Chapel Hill, and the Clinical Pathology Laboratory, College of Veterinary Medicine at North Carolina State University.

\section{RNA Extractions and cDNA Preparation}

RNA was extracted from TPC, kidney, and humerus samples using an RNeasy Midi Kit (Qiagen Inc., Valencia, Calif., USA). Quantitative analysis of the RNA sample was performed using an Agilent Bioanalyzer with Nano LabChip at the Genomic Core Facility, University of North Carolina at Chapel Hill. All RNA samples had RIN values in the range of 7.5-10. A High-Capacity Reverse Transcription Kit (Applied Biosciences, Carlsbad, Calif., USA) was used to prepare cDNA. After preparation, the cDNA was stored at $-80^{\circ} \mathrm{C}$.

\section{Quantitative Polymerase Chain Reaction}

cDNA samples free of genomic DNA contamination were subjected to quantitative polymerase chain reaction for a suite of genes including parathyroid hormone (Pth), calcium-sensing receptor (Casr), a-Klotho (aKlotho), fibroblast growth factor receptor 1c $(F g f 1 r c)$, vitamin D receptor $(V d r)$, parathyroid hormone-like hormone (Pthlh), tumor necrosis factor 11 (Tnfs11), fibroblast growth factor 23 (Fgf23), parathyroid hormone receptor 1 (Pth1r), chloride channel 5 (Clcn5), solute carrier 9 member 3 regulator 1 (Slc9a3r1), PDZ domain-containing 1 (Pdzk1), and solute carrier family 34 member 1 (Slc34a1). Expression of these genes was normalized using 2 housekeeping genes comprising $\beta$-actin (Actb) and glyceraldehyde 3-phosphate dehydrogenase (Gapdh). Thyroperoxidase (Tpo) was used as a surrogate marker for the quality of the TPC dispersed cell culture. All of the primers were from SA Biosciences (Qiagen). Data were analyzed using the $2^{-\Delta \Delta C t}$ method [Livak and Schmittgen, 2001; Yuan et al., 2006].

Fluoride Modulates PTH Secretion
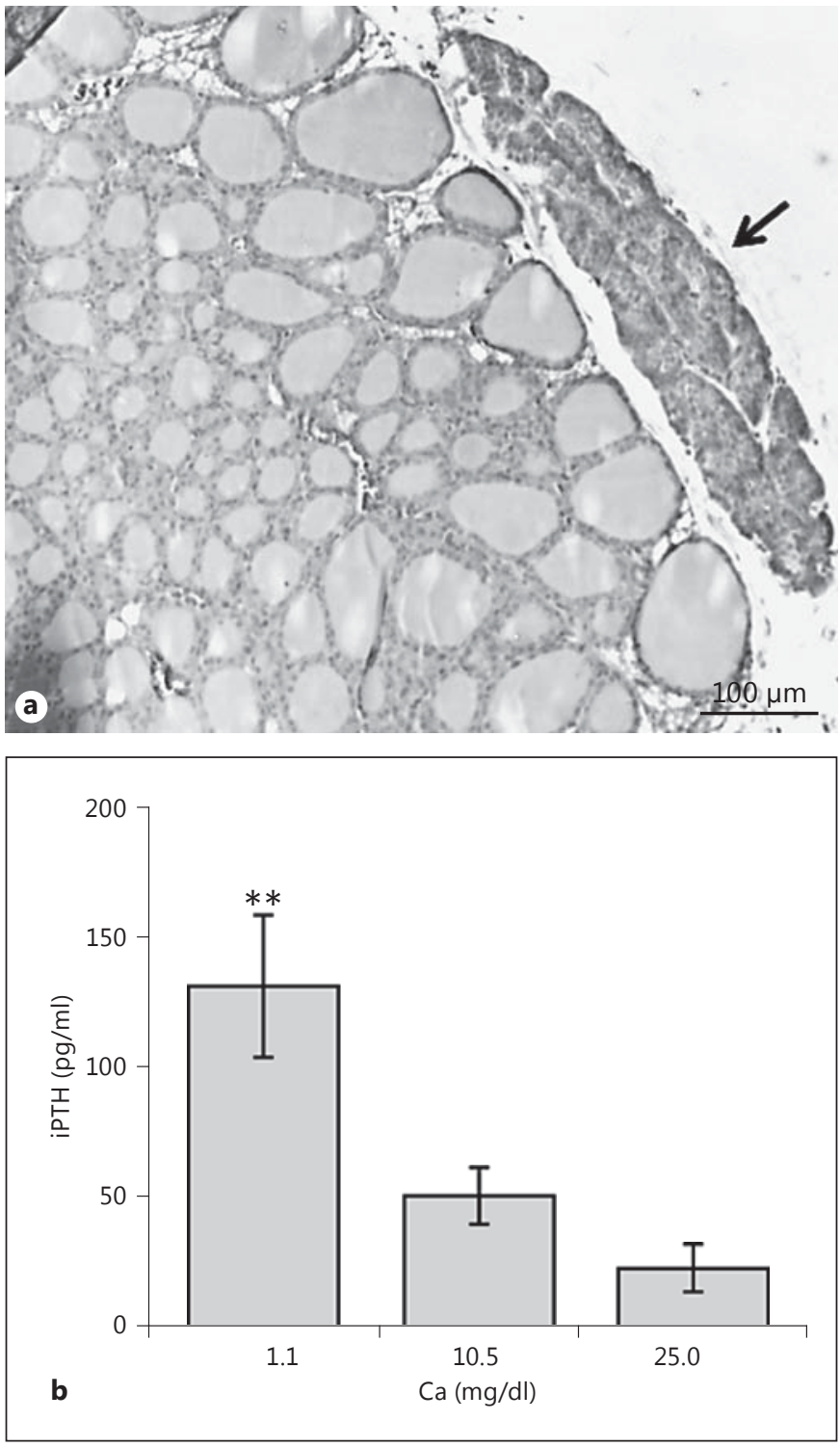

Fig. 1. TPC histology and iPTH levels in supernatant media. a Histological section of TPC; the arrow indicates parathyroid tissue. b $\mathrm{iPTH} \pm \mathrm{SE}$ in $\mathrm{C} 3 \mathrm{H}$ TPC at 3 calcium concentrations $(1.1,10.5$, and $25 \mathrm{mg} / \mathrm{dl} ; \mathrm{n}=3$ in each group). ${ }^{* *} \mathrm{p}<0.001$.

\section{Statistical Analysis}

Data are reported as means \pm SE. One-way ANOVA was used to compare the effect of calcium concentration on iPTH secretion in the TPC dispersed cell culture model. For in vitro experiments, 6 groups (each consisting of 6 mice) were compared using a 2-way ANOVA based on strain ( $\mathrm{C} 3 \mathrm{H}$ or $\mathrm{B} 6)$ and the level of fluoride exposure $(0,250$, or $500 \mu \mathrm{M})$. For in vivo experiments, 24 groups were compared using a 3-way ANOVA based on strain ( $\mathrm{C} 3 \mathrm{H}$ or $\mathrm{B} 6)$, the level of fluoride exposure ( 0 or $100 \mathrm{ppm})$, and time points $(0.5,1$, $3,6,12$, and $24 \mathrm{~h}$ ). A preliminary 2-way ANOVA was first used to confirm the absence of a time effect on water gavage when baseline 
gavage $(0 \mathrm{~h})$ was included for both strains of mice (total $\mathrm{n}=84$ ), which would justify the omission of baseline gavage data at $0 \mathrm{~h}$ in order to maintain balance in the 3-way ANOVA. Three-way ANOVA were also evaluated for serum total calcium, phosphorus, and magnesium levels for each strain followed by treatment with 0 or $100 \mu \mathrm{M}$ fluoride concentrations at $0.5,1,3,6,12$, and $24 \mathrm{~h}$. A natural $\log$ transformation was used for $\mathrm{PTH}$ and serum fluoride (but not for calcium, magnesium, or phosphorus) to address skewness. ANOVA main effect and interaction $p$ values $\leq 0.05$ were considered statistically significant, followed by Bonferroni adjustments for post hoc comparisons of levels of factors. SAS version 9.3 (SAS Inc., Cary, N.C., USA) was used for statistical analysis.

\section{Results}

\section{Responsiveness of the TPC Dispersed Cell}

Culture Model

The TPC (fig. 1a) dispersed cell culture model was utilized in order to determine the direct effects of fluoride on the parathyroid gland. All TPC dispersed cell cultures demonstrated Tpo gene expression (a surrogate marker for TPC dispersed cell culture quality) with a Ct value of $24.8 \pm 2.1$. The responsiveness of the dispersed cell culture model to changes in extracellular calcium, a known PTH mediator, was used to validate the culture model. TPC cultured in varying calcium concentrations (hypocalcemic: $1.1 \mathrm{mg} / \mathrm{dl}$, normocalcemic: $10.5 \mathrm{mg} / \mathrm{dl}$, or hypercalcemic: $25 \mathrm{mg} / \mathrm{dl}$ ) demonstrated changes in iPTH secretion into the media $(\mathrm{p}<0.001)$. Based on a Bonferroni-corrected significance level of $0.05 / 3=0.017$ and after $24 \mathrm{~h}$ of incubation in the hypocalcemic condition, iPTH secretion $(129.4 \pm 27.1 \mathrm{pg} / \mathrm{ml})$ was significantly increased ( $\mathrm{p}=0.007)$ compared to the normocalcemic condition $(49.2 \pm 6.2 \mathrm{pg} / \mathrm{ml}$ ) (fig. 1b). The hypercalcemic condition led to a further statistically significant decline in $\mathrm{iPTH}$ relative to the normocalcemic condition $(\mathrm{p}=$ 0.012). Though not shown, TPC in culture remained responsive to changes in calcium for 3 days.

\section{Effect of Fluoride on TPC}

The fluoride exposure experiments using TPC from $\mathrm{B} 6$ and $\mathrm{C} 3 \mathrm{H}$ mice were performed at 2 different times. In an initial experiment, TPC from $\mathrm{B} 6(\mathrm{n}=6)$ and $\mathrm{C} 3 \mathrm{H}(\mathrm{n}=$ 6) mice were cultured in media normalized to calcium, phosphorus, and magnesium levels present in the sera for each strain. Calcium, phosphorus, and magnesium are known modulators of iPTH and can serve as confounding variables and hence were kept at the levels commonly seen in the sera of each strain. Hence, constant levels of calcium, phosphorus, and magnesium were present in the test and control groups. This was followed by treatment

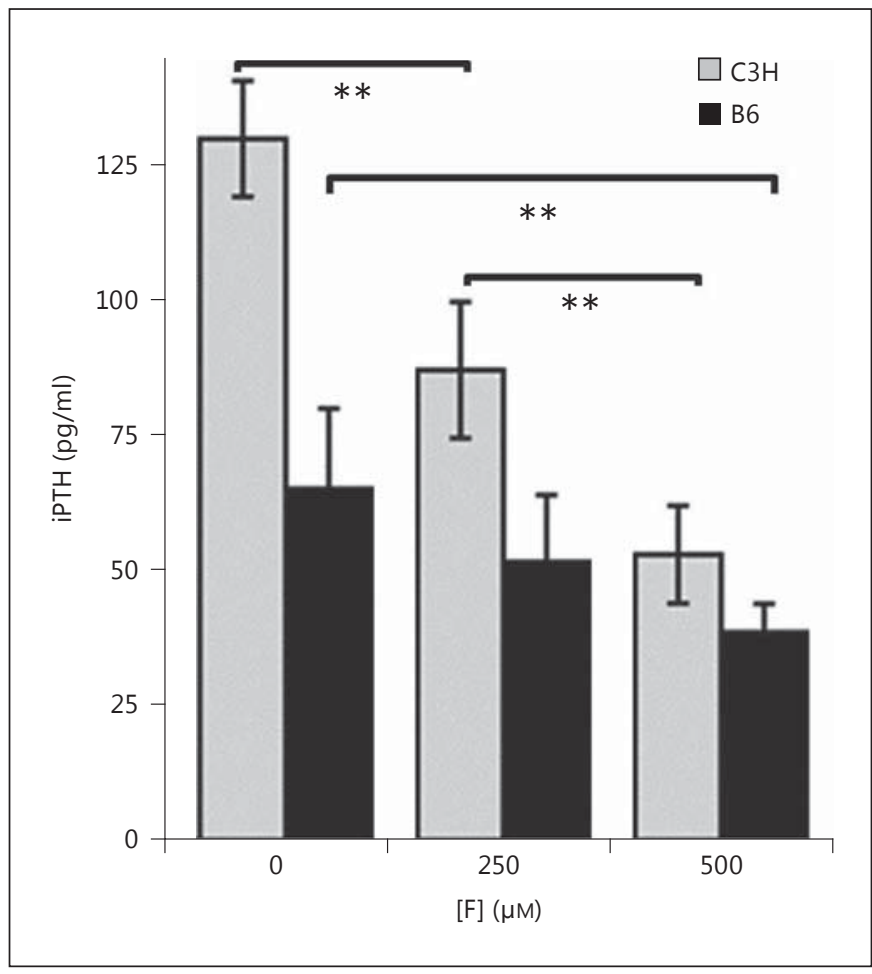

Fig. 2. iPTH levels in supernatant media (in vitro study). Mean $\mathrm{iPTH} \pm \mathrm{SE}$ in $\mathrm{C} 3 \mathrm{H}$ and $\mathrm{B} 6 \mathrm{TPC}$ after $24 \mathrm{~h}$ of incubation at 3 fluoride concentrations $(0,250$, and $500 \mu \mathrm{M} ; \mathrm{n}=6$ in each group; ** $\mathrm{p}<0.005)$.

with 2 fluoride concentrations ( 0 and $500 \mu \mathrm{M})$. Media supernatants were collected at $24 \mathrm{~h}$ and iPTH levels were determined. TPC from $\mathrm{C} 3 \mathrm{H}$ mice demonstrated a significant $(\mathrm{p}<0.001)$ decrease in iPTH with increasing fluoride concentrations from $0 \mu \mathrm{M}(145.7 \pm 13.1 \mathrm{pg} / \mathrm{ml})$ to 500 $\mu \mathrm{M}(72.2 \pm 5.9 \mathrm{pg} / \mathrm{ml})$. TPC from B6 mice demonstrated a similar decrease $(\mathrm{p}<0.001)$ in iPTH with increasing fluoride concentrations from $0 \mu \mathrm{M}(88.3 \pm 6.1 \mathrm{pg} / \mathrm{ml})$ to $500 \mu \mathrm{M}(47.1 .1 \pm 5.3 \mathrm{pg} / \mathrm{ml})$. A replicate experiment was performed using TPC from B6 $(n=6)$ and $\mathrm{C} 3 \mathrm{H}(\mathrm{n}=6)$ mice cultured in media normalized with calcium, phosphorus, and magnesium as described above and then followed by treatment with varying fluoride concentrations $(0,250$, and $500 \mu \mathrm{M})$. Media supernatants were collected at $24 \mathrm{~h}$ and $\mathrm{iPTH}$ levels were determined. In the 2 -way ANOVA, main effects (both $\mathrm{p}<0.001$ ) and interaction $(\mathrm{p}=0.042)$ were statistically significant, indicating that iPTH differs significantly between the 2 strains and the 3 fluoride levels, with the effect of fluoride exposure on $\mathrm{iPTH}$ being different for $\mathrm{C} 3 \mathrm{H}$ versus $\mathrm{B} 6$. Based on a Bonferroni-corrected significance level of $0.05 / 6=0.008$, for 


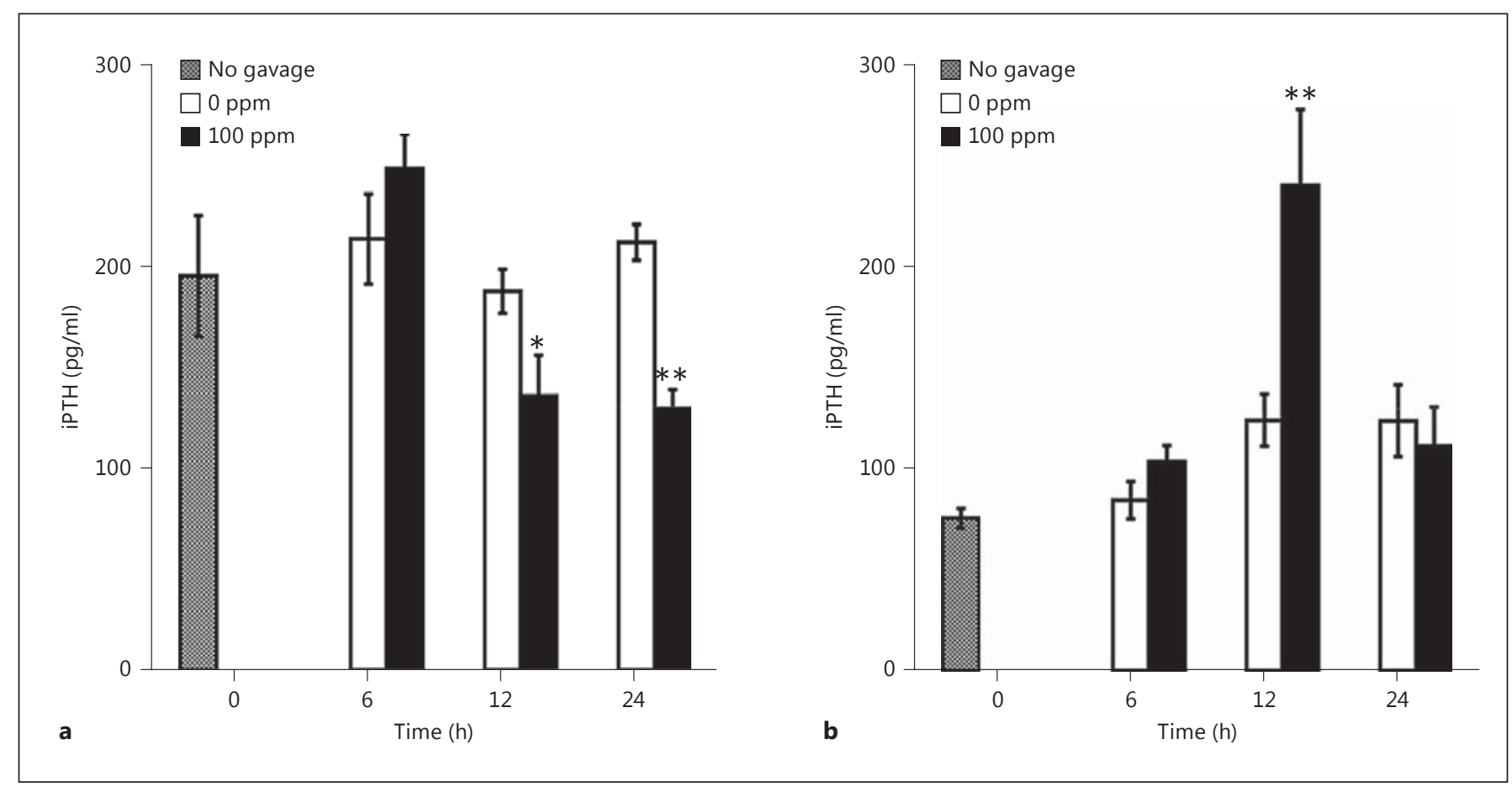

Fig. 3. Serum iPTH levels at $0,6,12$, and $24 \mathrm{~h}$. Mean serum iPTH $\pm \mathrm{SE}$ after 0 or $100 \mathrm{ppm}$ fluoride gavage in $\mathrm{C} 3 \mathrm{H}$ (a) and B6 (b) mice sacrificed at serial time points $(0,6,12$, and $24 \mathrm{~h})$ compared to untreated mice $(\mathrm{n}=6$ in each group; Bonferroni-corrected significance level; $\left.{ }^{*} \mathrm{p}<0.008,{ }^{* *} \mathrm{p}<0.001\right)$.

$\mathrm{C} 3 \mathrm{H}$, all 3 levels of fluoride exposure were significantly different from one another, with a higher fluoride level leading to a lower value of iPTH as follows: $0 \mu \mathrm{M}(128.5 \pm$ $10.6 \mathrm{pg} / \mathrm{ml})$ to $250 \mu \mathrm{M}(86.2 \pm 12.4 \mathrm{pg} / \mathrm{ml}, \mathrm{p}<0.001)$ or $500 \mu \mathrm{M}(52.3 \pm 8.9 \mathrm{pg} / \mathrm{ml}, \mathrm{p}<0.001)$. TPC from B6 mice demonstrated less of a decrease in $\mathrm{PPTH}$ with increasing fluoride concentrations from $0 \mu \mathrm{M}(64.3 \pm 14.7 \mathrm{pg} / \mathrm{ml})$ to $250 \mu \mathrm{M}(50.9 \pm 12.2 \mathrm{pg} / \mathrm{ml})$ or $500 \mu \mathrm{M}(38.1 \pm 5.1 \mathrm{pg} / \mathrm{ml})$, with the only significant pairwise comparison relating to fluoride concentrations at 0 versus $500 \mu \mathrm{M}(\mathrm{p}<0.001)$ (fig. 2). In the initial and replicate studies, $\mathrm{C} 3 \mathrm{H}$ had higher initial iPTH levels in the media compared to B6 TPC $(\mathrm{p}<0.01)$. TPC from both strains showed $\mathrm{F}$ dose-dependent decreases in iPTH secretion at $24 \mathrm{~h}$.

\section{Serum iPTH after a Single Fluoride Dose via \\ Orogastric Gavage}

As in the in vitro experiments, in vivo studies were done in two different instances. The initial experiment involved 42 mice per strain. Serum iPTH in $\mathrm{C} 3 \mathrm{H}$ and B6 mice was measured at 4 time points (baseline and 6, 12, and $24 \mathrm{~h}$ ) after fluoride gavage $\left(0.001 \mathrm{mg}\left[\mathrm{F}^{-}\right] / \mathrm{g}\right.$ of body weight) or gavage with an equal volume of $0 \mathrm{ppm}$ fluoride water. At baseline with $0 \mathrm{ppm}$ fluoride water gavage, the hour effect was not significant for main effect and interaction, and therefore the baseline observations were dropped from the analysis. The 3-way interaction between strain, hour, and gavage was not significant, but all 2-way interactions were significant (strain $\times$ gavage: $\mathrm{p}=$ 0.001 , strain $\times$ hour: $p<0.001$, gavage $\times$ hour: $p=0.009$ ). Although significance was not reached, at $6 \mathrm{~h}$ after 100 ppm fluoride gavage, serum iPTH levels increased modestly for C3H $(243.9 \pm 13.4 \mathrm{pg} / \mathrm{ml})$ and B6 $(102.1 \pm 7.3 \mathrm{pg} /$ $\mathrm{ml})$ compared to baseline untreated levels $(\mathrm{C} 3 \mathrm{H}: 210.5 \pm$ $16.2 \mathrm{pg} / \mathrm{ml}$ and B6: $86.6 \pm 8.9 \mathrm{pg} / \mathrm{ml}$ ) and control levels (0 ppm fluoride gavage; $\mathrm{C} 3 \mathrm{H}: 189.1 \pm 19.8 \mathrm{pg} / \mathrm{ml}$ and $\mathrm{B} 6$ : $77.1 \pm 4.8 \mathrm{pg} / \mathrm{ml})$. In the $\mathrm{C} 3 \mathrm{H}$ strain, iPTH dropped below baseline at $24 \mathrm{~h}(126.7 \pm 10.2 \mathrm{pg} / \mathrm{ml}, \mathrm{p}<0.001)$ (fig. 3a), whereas in B6 iPTH increased at $12 \mathrm{~h}(234.8 \pm 34.1 \mathrm{pg} / \mathrm{ml}$, $\mathrm{p}<0.001$ ) after $100 \mathrm{ppm}$ fluoride gavage (fig. 3b).

The in vivo studies were replicated using an additional 78 mice per strain. As before, serum iPTH was measured at various time points $(0,0.5,1,3,6,12$, and $24 \mathrm{~h})$ in $\mathrm{C} 3 \mathrm{H}$ and $\mathrm{B} 6$ mice after fluoride gavage $(0.001 \mathrm{mg}$ $\left[\mathrm{F}^{-}\right] / \mathrm{g}$ body weight) or gavage with an equal volume of 0 ppm fluoride water. A preliminary 2-way ANOVA re- 


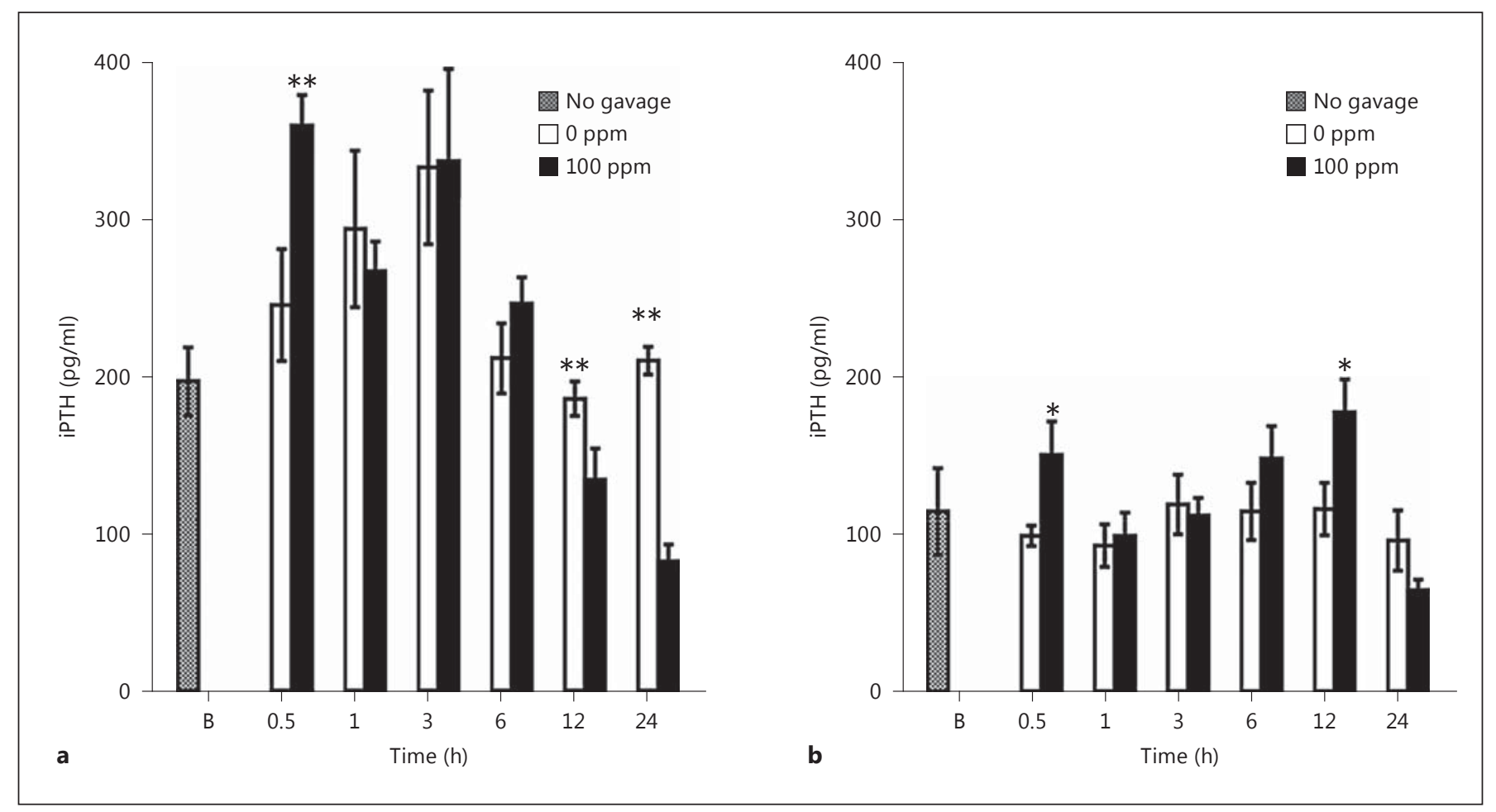

Fig. 4. Serum iPTH levels at $0.5,1,3,6,12$, and $24 \mathrm{~h}$. Mean serum $\mathrm{PPTH} \pm \mathrm{SE}$ after 0 or $100 \mathrm{ppm}$ fluoride gavage in $\mathrm{C} 3 \mathrm{H}(\mathbf{a})$ and B6 (b) mice sacrificed at serial time points $(0.5,1,3,6,12$, and $24 \mathrm{~h})$ compared to untreated mice $\left(\mathrm{n}=6\right.$ in each group; $\left.{ }^{*} \mathrm{p}<0.05,{ }^{* *} \mathrm{p}<0.005\right) . \mathrm{B}=$ Baseline.

stricted to baseline gavage $0 \mu \mathrm{M}$ fluoride at 6 time points and strain as the second factor gave a nonsignificant interaction and a nonsignificant time effect consistent with the assumption of no differences between the mean serum iPTH for baseline gavage $(0 \mathrm{~h})$ and $0 \mu \mathrm{M}$ fluoride at any time point. In the 3-way ANOVA, the 3-way interaction was not statistically significant, but all 2 -way interactions were significant (strain $\times$ gavage: $p=0.017$, strain $\times$ hour: $p<0.001$, gavage $\times$ hour: $p<0.001$ ). This means that each factor has effects on iPTH that vary across the levels of a second factor when averaged over the third factor. Based on a Bonferroni-corrected significance level of $0.05 / 6=0.008$, fluoride levels of 0 and $100 \mathrm{ppm}$ have a statistically different mean iPTH only at $0.5 \mathrm{~h}(\mathrm{p}=0.004)$ and $24 \mathrm{~h}(\mathrm{p}<0.0001)$ for either strain. Specifically, at $0.5 \mathrm{~h}$, gavage with a fluoride level of $100 \mathrm{ppm}$ yielded $\mathrm{C} 3 \mathrm{H}$ $(358.4 \pm 19.4 \mathrm{pg} / \mathrm{ml})$ and $\mathrm{B} 6[149.9 \pm 21.2 \mathrm{pg} / \mathrm{ml} \mathrm{com}-$ pared to control (0 ppm fluoride gavage) levels $(\mathrm{C} 3 \mathrm{H}$ : $244.4 \pm 35.5 \mathrm{pg} / \mathrm{ml}$ and B6: $98.6 \pm 6.4 \mathrm{pg} / \mathrm{ml}$ )]. However, gavage with a fluoride level of $0 \mathrm{ppm}$ yielded higher mean iPTH levels at $24 \mathrm{~h}(\mathrm{p} \leq 0.001)$. In the $\mathrm{C} 3 \mathrm{H}$ strain, iPTH dropped below baseline at $24 \mathrm{~h}(82.0 \pm 10.7 \mathrm{pg} / \mathrm{ml}, \mathrm{p}=$
0.002) (fig. 4a), whereas in B6, iPTH increased at $12 \mathrm{~h}$ $(176.9 \pm 20.8 \mathrm{pg} / \mathrm{ml}, \mathrm{p}<0.001)$ and then returned to baseline at $24 \mathrm{~h}(95.6 \pm 19.9 \mathrm{pg} / \mathrm{ml})$ (fig. $4 \mathrm{~b})$. The peak iPTH value in $\mathrm{C} 3 \mathrm{H}(358.4 \pm 19.4 \mathrm{pg} / \mathrm{ml})$ was twice the magnitude of the peak iPTH value in $\mathrm{B} 6(176.9 \pm 20.8 \mathrm{pg} / \mathrm{ml})$.

Since the iPTH levels in $\mathrm{C} 3 \mathrm{H}$ mice dropped below baseline at $24 \mathrm{~h}$, additional time points up to $96 \mathrm{~h}$ were examined. The serum iPTH in $\mathrm{C} 3 \mathrm{H}$ mice after a single 100 -ppm fluoride gavage returned to baseline at $48 \mathrm{~h}$ (fig. 5). These data demonstrated a difference in the effects of fluoride on iPTH secretion in 2 mice strains: $\mathrm{C} 3 \mathrm{H}$ and B6.

\section{Serum Fluoride Levels after Gavage}

A calculated dose of fluoride was delivered by orogastric gavage. Serum fluoride concentrations were measured at serial time points $(0.5,1,3,6,12$, and $24 \mathrm{~h})$ after a single gavage dose. The fluoride levels in the serum peaked in both strains, i.e. C3H $(61.0 \pm 5.6 \mu \mathrm{M})$ and $\mathrm{B} 6$ $(26.7 \pm 3.1 \mu \mathrm{M}), 0.5 \mathrm{~h}(\mathrm{p}<0.001)$ after gavage. Fluoride levels reached baseline $(0 \mathrm{ppm})$ in $\mathrm{C} 3 \mathrm{H}(8.7 \pm 1.7 \mu \mathrm{M})$ and B6 $(3.5 \pm 0.4 \mu \mathrm{M})$ after $6-9 \mathrm{~h}$ (fig. 6). The interaction be- 


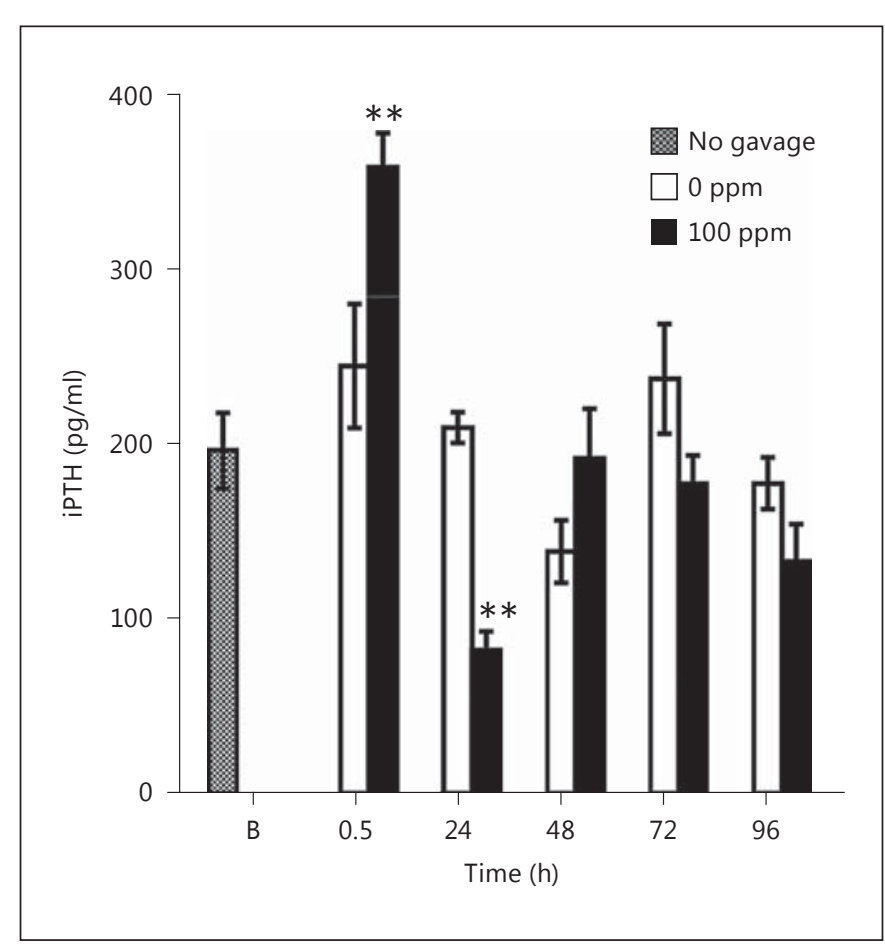

Fig. 5. Serum iPTH levels at 48-96 h. Mean serum iPTH $\pm \mathrm{SE}$ (pg/ $\mathrm{ml}$ ) after 0 or $100 \mathrm{ppm}$ fluoride gavage in $\mathrm{C} 3 \mathrm{H}$ mice harvested at extended time points $(48,72$, and $96 \mathrm{~h})$ compared to untreated mice $\left(\mathrm{n}=6\right.$ in each group; $\left.{ }^{* *} \mathrm{p}<0.005\right) . \mathrm{B}=$ Baseline.

tween hour and strain was significant $(\mathrm{p}<0.0001)$, indicating that the pattern of fluoride kinetics is different across the strains. In particular, fluoride levels in B6 were significantly lower than in $\mathrm{C} 3 \mathrm{H}$ at $0.5,1,3$, and $12 \mathrm{~h}(\mathrm{p}<$ $0.001)$. The peak fluoride concentration in $\mathrm{C} 3 \mathrm{H}(61.0 \pm$ $5.6 \mu \mathrm{M})$ was nearly twice that in B6 $(26.7 \pm 3.1 \mu \mathrm{M})$.

\section{Serum Total Calcium, Phosphorus, and Magnesium Levels}

Serum total calcium levels were relatively consistent between 0 and $100 \mathrm{ppm}$ fluoride gavage in both $\mathrm{C} 3 \mathrm{H}$ (fig. 7a) and B6 mice (fig. 7d). We observed a significant reduction $(\mathrm{p}<0.05)$ in serum total calcium only at $0.5 \mathrm{~h}$ in the $100 \mathrm{ppm}$ fluoride gavage group $(\mathrm{C} 3 \mathrm{H}: 8.7 \pm 0.2 \mathrm{mg}$ / $\mathrm{dl}$ and B6: $8.5 \pm 0.2 \mathrm{mg} / \mathrm{dl}$ ) compared to the $0 \mathrm{ppm}$ control $(\mathrm{C} 3 \mathrm{H}: 8.9 \pm 0.1 \mathrm{mg} / \mathrm{dl}$ and $\mathrm{B} 6: 9.5 \pm 0.2 \mathrm{mg} / \mathrm{dl})$ and untreated baseline (C3H: $9.3 \pm 0.1 \mathrm{mg} / \mathrm{dl}$ and $\mathrm{B} 6: 9.2 \pm 0.2$ $\mathrm{mg} / \mathrm{dl}$ ) groups.

The strain $\times$ gavage interaction in the 2-way ANOVA for serum phosphorus levels was significant $(p=0.034)$. Hour was removed from the model as it was not statistically significant. Therefore, when time was not consid-

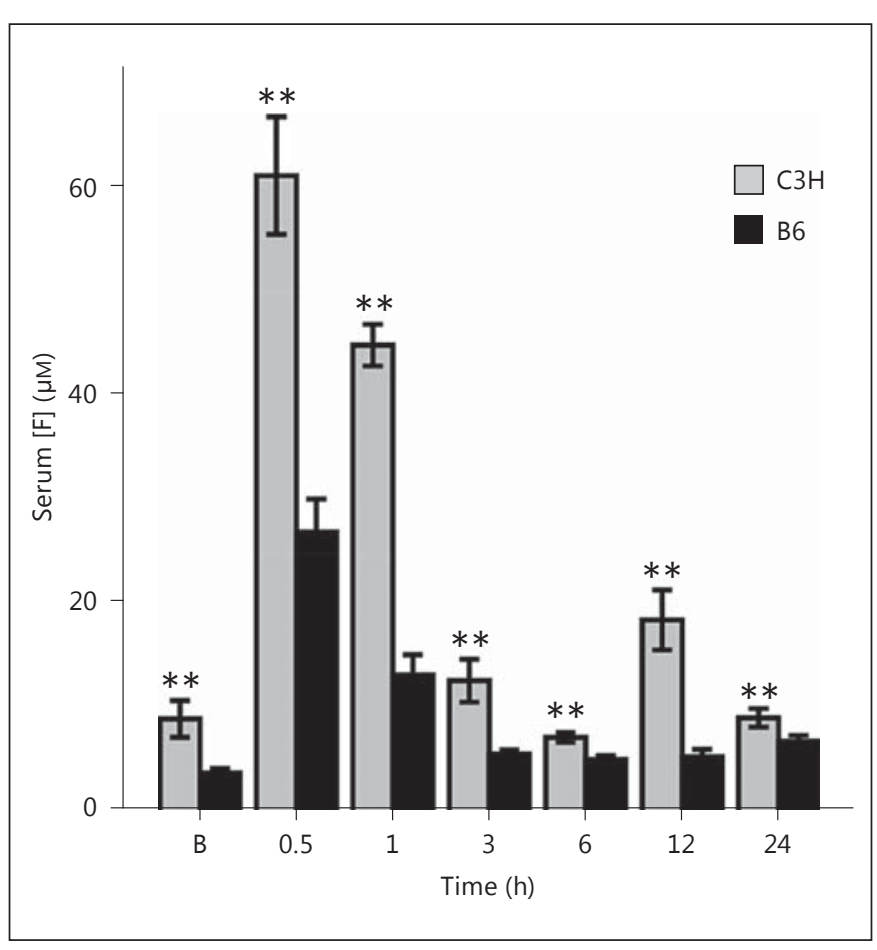

Fig. 6. Serum fluoride levels. Mean serum fluoride \pm SE after 100 ppm fluoride gavage in $\mathrm{C} 3 \mathrm{H}$ and $\mathrm{B} 6$ mice sacrificed at serial time points $(0.5,1,3,6,12$, and $24 \mathrm{~h})$ compared to baseline (no gavage) $\left(\mathrm{n}=6\right.$ in each group; $\left.{ }^{* *} \mathrm{p}<0.005\right) . \mathrm{B}=$ Baseline.

ered, there was an overall difference between 0 and 100 ppm fluoride gavage for $\mathrm{C} 3 \mathrm{H}(\mathrm{p}=0.009)$ (fig. $7 \mathrm{~b}$ ) but not for B6 (fig. 7e) mice. No statistically significant differences in magnesium levels were observed between 0 and 100 ppm fluoride gavage at any time point for either $\mathrm{C} 3 \mathrm{H}$ (fig. 7c) or B6 (fig. 7f) mice.

\section{Quantitative Polymerase Chain Reaction: Expression of Genes Involved in the BPK Feedback Loop}

We investigated the expression of various genes involved in the BPK feedback loop using TPC, humeri, and kidneys. Expression of the genes in tissues obtained from $100 \mathrm{ppm}$ fluoride gavage $\mathrm{C} 3 \mathrm{H}$ and $\mathrm{B} 6$ mice at $24 \mathrm{~h}$ were normalized with an average of 2 housekeeping genes (Actb and Gapdh). Gene expression was further normalized to the control $0 \mathrm{ppm}$ fluoride gavage group, and fold differences of genes in TPC (fig. 8a), humeri (fig. 8b), and kidneys (fig. 8c) were calculated for $\mathrm{C} 3 \mathrm{H}$ and $\mathrm{B} 6$ mice using the $2^{-\Delta \Delta \mathrm{Ct}}$ method. In TPC, Pth $(\mathrm{p}=0.001), \operatorname{Casr}(\mathrm{p}=$ $0.012), \alpha$ Klotho $(\mathrm{p}=0.003), F g f 1 r c(\mathrm{p}=0.035), V d r(\mathrm{p}=$ $0.001)$, and Pthlh $(\mathrm{p}=0.03)$ were significantly upregulated in $\mathrm{C} 3 \mathrm{H}$ compared to B6. In humeri, only Pthlh ( $\mathrm{p}=$ 


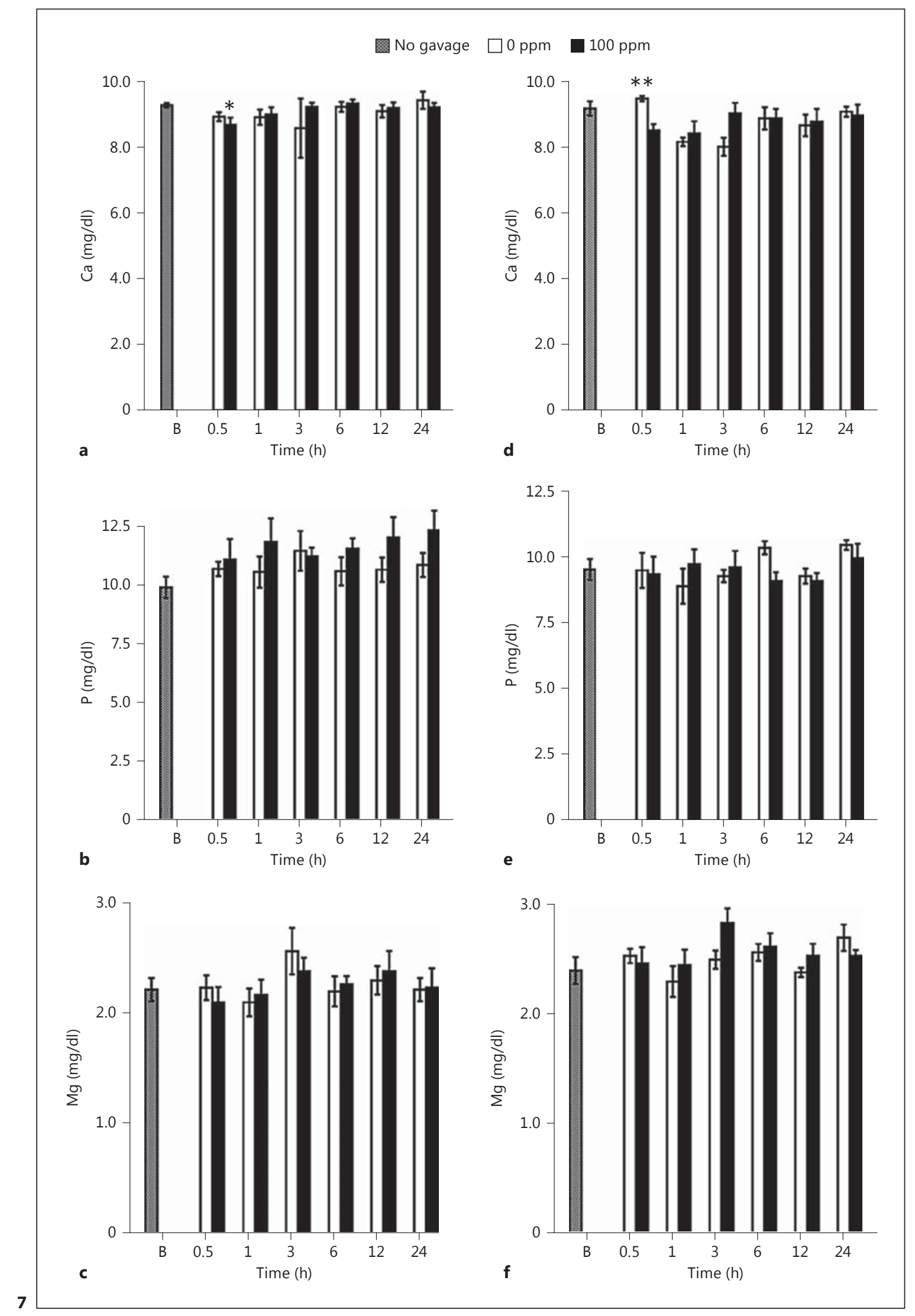

(For legend see next page.) 


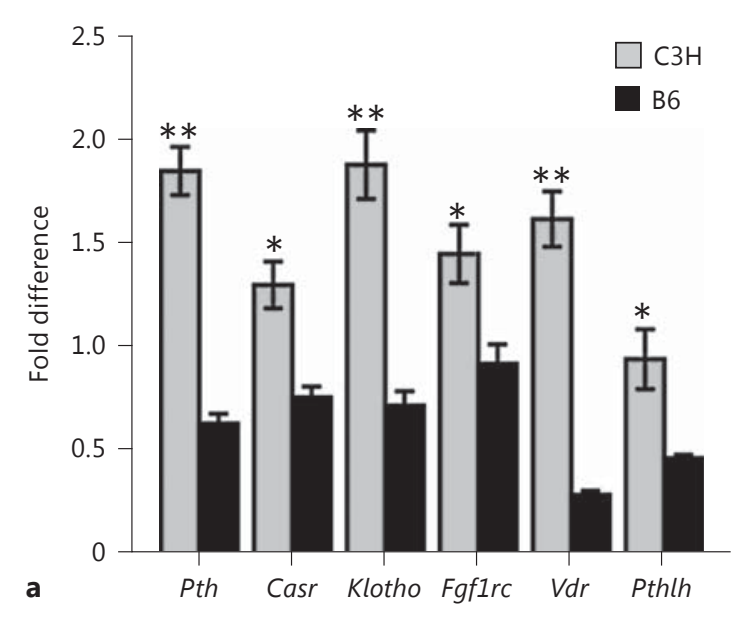

$0.001)$ was significantly upregulated in $\mathrm{C} 3 \mathrm{H}$ compared to B6 mice. In kidneys, Pthlr ( $\mathrm{p}=0.005), \operatorname{Clcn} 5(\mathrm{p}=0.003)$, $\alpha$ Klotho $(\mathrm{p}=0.05)$, Fgf1rc $(\mathrm{p}=0.004)$, and Slc9a3r1 ( $\mathrm{p}=$ 0.04 ) were significantly downregulated in $\mathrm{C} 3 \mathrm{H}$ compared to B6.

\section{Discussion}

Skeletal fluorosis is characterized by a spectrum of radiographic bone changes ranging from osteoporosis to osteosclerosis [Wang et al., 1994]. Although clinical cases of skeletal fluorosis are rare in the USA [Kurland et al., 2007; Whyte et al., 2008], in other parts of the world where skeletal fluorosis is more common, patients often demonstrate pseudo-hyperparathyroidism [Teotia and Teotia, 1973; Teotia et al., 1998; Gupta et al., 2001; Xu et al., 2010; Koroglu et al., 2011]. Epidemiologic studies have shown that individuals of a population exposed to similar fluoride levels demonstrate variable skeletal features ranging from excessive bone formation to bone resorption [Teotia et al., 1998; Harinarayan et al., 2006]. Therefore, the mechanisms that underlie the actions of fluoride on the bone and PTH are not clearly understood. Yan et al. [2007] demonstrated a link between fluoride exposure and $\mathrm{PTH}$ levels using the $\mathrm{C} 3 \mathrm{H}$ and $\mathrm{B} 6$ inbred strains of mice. Fluoride exposure in $\mathrm{C} 3 \mathrm{H}$ led to enhanced osteoclastogenesis including elevated serum iPTH, whereas in B6 an anabolic action of fluoride was favored. Additionally, these strains are widely studied for their differences in bone biology. $\mathrm{C} 3 \mathrm{H}$ mice have a high bone mass, peak bone density, and alkaline phosphatase activity and a low bone resorption capacity compared to B6 mice [Chen and Kalu, 1999; Linkhart et al., 1999; Turner et al., 2000, 2001].

Direct or indirect effects of fluoride on the parathyroid gland have not been investigated. We developed a murine TPC dispersed cell culture model using inbred

Fig. 7. Mean $( \pm \mathrm{SE})$ serum calcium $(\mathrm{Ca})$, phosphorus $(\mathrm{P})$, and magnesium $(\mathrm{Mg})$ levels after 0 or $100 \mathrm{ppm}$ fluoride gavage in $\mathrm{C} 3 \mathrm{H}$ (a-c, respectively) and B6 (d-f, respectively) mice harvested at serial time points $(0.5,1,3,6,12$, and $24 \mathrm{~h} ; \mathrm{n}=6$ in each group; $\left.{ }^{*} \mathrm{p}<0.05,{ }^{* *} \mathrm{p}<0.005\right) . \mathrm{B}=$ Baseline.

Fig. 8. Expression of genes involved in the BPK feedback loop. Fold difference $\pm \mathrm{SE}$ in the $\mathrm{C} 3 \mathrm{H}$ and $\mathrm{B} 6$ 100-ppm fluoride gavage groups normalized to the control, the 0-ppm fluoride group, and the housekeeping gene pool (Actb and Gapdh) in TPC (a), humeri (b), and kidneys $(\mathbf{c})\left(\mathrm{n}=6\right.$ in each group; $\left.{ }^{*} \mathrm{p}<0.05,{ }^{* *} \mathrm{p}<0.001\right)$. 
mouse strains with a predictable iPTH secretion response to changes in calcium. Similar TPC dispersed cell culture models have been employed using bovine, human, and rat parathyroid tissues to study parathyroid hormone regulation [Wongsurawat and Armbrecht, 1987; Nielsen et al., 1996; Nakajima et al., 2010]. Calcium, phosphorus, and magnesium are known to mediate changes in iPTH secretion and therefore the levels of these in the media were kept equivalent with strain-specific serum levels to prevent unwanted effects on iPTH secretion. In both $\mathrm{C} 3 \mathrm{H}$ and $\mathrm{B} 6$, fluoride exposure resulted in dose-dependent reductions in iPTH secretion into the media measured at $24 \mathrm{~h}$. This reduction was more evident for $\mathrm{C} 3 \mathrm{H}$, which at baseline secretes almost twice the iPTH that B6 does.

The fluoride kinetics observed for $\mathrm{B} 6$ and $\mathrm{C} 3 \mathrm{H}$ strains were consistent with previous studies where serum fluoride reached a peak within 20-30 min [Ekstrand et al., 1977; Whitford, 1994]. It is generally accepted that after absorption fluoride is incorporated in newly mineralized bone or is excreted in urine, resulting in a decline in serum levels, reaching baseline by $6-8 \mathrm{~h}$ [Ekstrand et al., 1980]. In order for fluoride to elicit a rapid iPTH response, it is hypothesized that fluoride interacts with the parathyroid gland directly through modulation of $\mathrm{iPTH}$ release from vesicles in the chief cells. The exact molecular mechanism of this response is not understood. However, our in vitro findings suggest the presence of such a direct interaction of fluoride on the parathyroid glands.

In the current study, $\mathrm{C} 3 \mathrm{H}$ mice had higher baseline serum iPTH levels compared to B6 mice. This is consistent with our TPC baseline values. $\mathrm{C} 3 \mathrm{H}$ mice were more responsive to the single fluoride exposure, perhaps because they reached a higher peak serum fluoride level. This enhanced response was shown after the gavage when the levels of iPTH were higher in $\mathrm{C} 3 \mathrm{H}$ compared to $\mathrm{B} 6$. At $24 \mathrm{~h}$, iPTH levels were lower than baseline values for both strains. Both strains also showed bimodal responses to fluoride. For $\mathrm{C} 3 \mathrm{H}, \mathrm{iPTH}$ peaked at $0.5 \mathrm{~h}$ and declined below baseline at $12 \mathrm{~h}$, reaching a nadir at $24 \mathrm{~h}$, and then over the next $24 \mathrm{~h}$ it returned to baseline and remained at baseline at $96 \mathrm{~h}$. B6 mice showed a similar but lower-magnitude response.

Modulation of iPTH secretion as a response to fluoride exposure may also be mediated by changes in calcium levels. Decreased serum calcium levels after acute hydrofluoric acid inhalation have been documented in humans [Zierold and Chauviere, 2012]. Acute exposure to fluoride through injection of hydrofluoric acid $(1.6 \mathrm{mg} / \mathrm{kg})$ in rats led to a decrease in serum ionized calcium and total calcium after 30 and $300 \mathrm{~min}$, respectively [Santoyo-Sanchez et al., 2013]. A similar decrease in plasma calcium has been observed in rats due to acute fluoride exposure [Imanishi et al., 2009]. The reduced serum calcium is hypothesized to be due to the formation of $\mathrm{CaF}_{2}$ complexes resulting in a net reduction in calcium levels leading to a hypocalcemic response. In our study, we observed a transient decrease in calcium in both strains of mice only at $0.5 \mathrm{~h}$, with a return to baseline within $1 \mathrm{~h}$. There were no significant changes in phosphorus or magnesium at any time point.

The BPK feedback loop has been extensively studied to understand the interaction of various genes involved in mineral homeostasis. The cross talk between bone, the parathyroid gland, and the kidney is responsible for effective regulation of minerals. The effect of fluoride on these individual tissues after a single fluoride dose in the 2 strains of mice will help us to understand the effect of fluoride on regulatory aspects of mineral homeostasis. Changes in gene expression patterns due to fluoride exposure have been studied in the past [Li and DenBesten, 1993; Nair et al., 2011; Pei et al., 2012], but our study focused only on the expression of the genes that are involved in calcium and phosphorus homeostasis and are part of the BPK feedback loop. Fold differences in the expression of Pth, Casr, $\alpha$ Klotho, Fgflrc, Vdr, and Pthlh in TPC suggest that at the molecular level fluoride has a differential impact on parathyroid tissues in $\mathrm{C} 3 \mathrm{H}$ and B6. The expression of these genes reflects a compensatory mechanism to counter changes in iPTH secretion. It is clear that fluoride effects are not limited to Pth but extend to Pth homologues such as Pthlh. Expression of Fgflrc- $\alpha$ Klotho (receptor couple for Fgf23) and Pth1r is suggestive of an effort to intercept conservation of calcium and excretion of phosphorus in the kidneys to achieve homeostasis after the initial iPTH secretion. Overall, there exists a difference in expression of BPK genes in the 2 strains of mice. This suggests a difference in physiologic handling of fluoride by the 2 strains. It will be interesting to study the effect of a repeated fluoride dose on expression of the key genes in $\mathrm{C} 3 \mathrm{H}$ and $\mathrm{B} 6$.

Our study investigated the early events involved in fluoride interaction on the parathyroid gland in vitro and in vivo. Fluoride can act on the parathyroid gland directly to modulate iPTH secretion in vitro and in vivo. It is still not clear if the decrease in total serum calcium levels is responsible for fluoride-mediated iPTH modulation. The effect of fluoride on iPTH secretion is rapid 
and observable even after a single fluoride dose. The overall effects of fluoride are not limited to the parathyroid gland, but changes in the expression of the genes involved in the BPK feedback loop suggest a broader impact of fluoride on multiple aspects of bone metabolism.

\section{Acknowledgements}

Ms. Staci Love is gratefully acknowledged for her help with in vitro studies. The research reported in this publication was supported by the National Institute of Dental and Craniofacial Research (NIDCR) of the National Institutes of Health under award No. R01DE018104 to E.T.E.

\section{References}

Bergwitz, C., H. Juppner (2010) Regulation of phosphate homeostasis by PTH, vitamin D, and FGF23. Annu Rev Med 61: 91-104.

Chen, C., D.N. Kalu (1999) Strain differences in bone density and calcium metabolism between $\mathrm{C} 3 \mathrm{H} / \mathrm{HeJ}$ and $\mathrm{C} 57 \mathrm{BL} / 6 \mathrm{~J}$ mice. Bone 25: 413-420.

Ekstrand, J., G. Alvan, L.O. Boreus, A. Norlin (1977) Pharmacokinetics of fluoride in man after single and multiple oral doses. Eur J Clin Pharmacol 12: 311-317.

Ekstrand, J., M. Ehrnebo, G.M. Whitford, P.O. Jarnberg (1980) Fluoride pharmacokinetics during acid-base balance changes in man. Eur J Clin Pharmacol 18: 189-194.

Everett, E.T. (2011) Fluoride's effects on the formation of teeth and bones, and the influence of genetics. J Dent Res 90: 552-560.

Gupta, S.K., T.I. Khan, R.C. Gupta, A.B. Gupta, K.C. Gupta, P. Jain, A. Gupta (2001) Compensatory hyperparathyroidism following high fluoride ingestion - a clinico-biochemical correlation. Indian Pediatr 38: 139-146.

Harinarayan, C.V., N. Kochupillai, S.V. Madhu, N. Gupta, P.J. Meunier (2006) Fluorotoxic metabolic bone disease: an osteo-renal syndrome caused by excess fluoride ingestion in the tropics. Bone 39: 907-914.

Imanishi, M., T. Dote, H. Tsuji, E. Tanida, E. Yamadori, K. Kono (2009) Time-dependent changes of blood parameters and fluoride kinetics in rats after acute exposure to subtoxic hydrofluoric acid. J Occup Health 51: 287293.

Koroglu, B.K., I.H. Ersoy, M. Koroglu, A. Balkarli, S. Ersoy, S. Varol, M.N. Tamer (2011) Serum parathyroid hormone levels in chronic endemic fluorosis. Biol Trace Elem Res 143: 79-86.

Kurland, E.S., R.C. Schulman, J.E. Zerwekh, W.R. Reinus, D.W. Dempster, M.P. Whyte (2007) Recovery from skeletal fluorosis (an enigmatic, American case). J Bone Miner Res 22: 163 170.

Li, R., P.K. DenBesten (1993) Expression of bone protein mRNA at physiological fluoride concentrations in rat osteoblast culture. Bone Miner 22: 187-196.
Linkhart, T.A., S.G. Linkhart, Y. Kodama, J.R. Torres, P.A., D.P. De Brauwere (2011) Three Farley, H.P. Dimai, K.R. Wright, J.E. Wergedal, M. Sheng, W.G. Beamer, L.R. Donahue, C.J. Rosen, D.J. Baylink (1999) Osteoclast formation in bone marrow cultures from two inbred strains of mice with different bone densities. J Bone Miner Res 14: 39-46.

Livak, K.J., T.D. Schmittgen (2001) Analysis of relative gene expression data using real-time quantitative PCR and the 2(-delta delta $\mathrm{C}(\mathrm{T}))$ method. Methods 25: 402-408. feedback loops precisely regulating serum phosphate concentration. Kidney Int 80: 443445.

Turner, C.H., Y.F. Hsieh, R. Muller, M.L. Bouxsein, D.J. Baylink, C.J. Rosen, M.D. Grynpas, L.R. Donahue, W.G. Beamer (2000) Genetic regulation of cortical and trabecular bone strength and microstructure in inbred strains of mice. J Bone Miner Res 15: 1126-1131.

Turner, C.H., Y.F. Hsieh, R. Muller, M.L. Bouxsein, C.J. Rosen, M.E. McCrann, L.R. Donahue, W.G. Beamer (2001) Variation in bone biomechanical properties, microstructure, and density in BXH recombinant inbred mice. J Bone Miner Res 16: 206-213. fuoride on expression of bone-specific genes in developing Xenopus laevis larvae. Biochem Cell Biol 89: 377-386.

Nakajima, K., T. Okazaki, T. Okamoto, H. Kimura, K. Takano, K. Sato (2010) Genes up- or down-regulated by high calcium medium in parathyroid tissue explants from patients with primary hyperparathyroidism. Endocr J 57: 153-159.

- Nielsen, P.K., U. Feldt-Rasmussen, K. Olgaard (1996) A direct effect in vitro of phosphate on PTH release from bovine parathyroid tissue slices but not from dispersed parathyroid cells. Nephrol Dial Transplant 11: 1762-1768.

Pei, J., B. Li, Y. Gao, Y. Wei, L. Zhou, H. Yao, J. Wang, D. Sun (2012) Fluoride decreased osteoclastic bone resorption through the inhibition of NFATc1 gene expression. Environ Toxicol 29: 588-595.

Potts, J.T. (2005) Parathyroid hormone: past and present. J Endocrinol 187: 311-325.

Santoyo-Sanchez, M.P., M. del Carmen Silva-Lucero, L. Arreola-Mendoza, O.C. Barbier (2013) Effects of acute sodium fluoride exposure on kidney function, water homeostasis, and renal handling of calcium and inorganic phosphate. Biol Trace Elem Res 152: 367-372.

Vogel, G.L., C.M. Carey, L.C. Chow, J. Ekstrand (1990) Fluoride analysis in nanoliter- and microliter-size fluid samples. J Dent Res 69: 522528, discussion 556-527.

Wang, Y., Y. Yin, L.A. Gilula, A.J. Wilson (1994) Endemic fluorosis of the skeleton: radiographic features in 127 patients. AJR Am J Roentgenol 162: 93-98.

Whitford, G.M. (1994) Intake and metabolism of fluoride. Adv Dent Res 8: 5-14.

Whyte, M.P., W.G. Totty, V.T. Lim, G.M. Whitford (2008) Skeletal fluorosis from instant tea. J Bone Miner Res 23: 759-769.

Wongsurawat, N., H.J. Armbrecht (1987) Comparison of calcium effect on in vitro calcitonin and parathyroid hormone release by young and aged thyroparathyroid glands. Exp Gerontol 22: 263-269.

Xu, H., Q.Y. Liu, J.M. Zhang, H. Zhang, G.S. Li (2010) Elevation of PTH and PTHrp induced by excessive fluoride in rats on a calcium-deficient diet. Biol Trace Elem Res 137: 79-87.

Yan, D., A. Gurumurthy, M. Wright, T.W. Pfeiler, E.G. Loboa, E.T. Everett (2007) Genetic background influences fluoride's effects on osteoclastogenesis. Bone 41: 1036-1044. parathyroidism in patients with endemic skeletal fluorosis. Br Med J 1: 637-640.

Teotia, M., S.P. Teotia, K.P. Singh (1998) Endemic chronic fluoride toxicity and dietary calcium deficiency interaction syndromes of metabolic bone disease and deformities in India: year 2000. Indian J Pediatr 65: 371-381.
Yuan, J.S., A. Reed, F. Chen, C.N. Stewart Jr (2006) Statistical analysis of real-time PCR data. BMC Bioinformatics 7: 85.

Zierold, D., M. Chauviere (2012) Hydrogen fluoride inhalation injury because of a fire suppression system. Mil Med 177: 108-112. 